\title{
HIGHER ED
}

March 2015 http://elearnmag.acm.org/featured.cfm?aid=2749226

\section{Mobile Learning in Higher education: Mobilizing staff to use technologies in their teaching}

Given the ubiquity of mobile devices being used by students in their university, a group of lecturers formed an action-learning group to learn collaboratively about enhancing their teaching with mobile pedagogies. The community of learners developed a process for setting goals for themselves, and for implementing action plans to do with integrating mobile technologies in teaching. The article discusses the processes used and the lessons learned through this project. These findings have informed work done with schools that are trying to integrate mobile learning into their classrooms.

A Professor of Education shares her lessons learned in upskilling her colleagues to integrate mobile technology into their teaching.

\section{By Sandy Schuck}

Almost everybody has a mobile device of some sort or another, be it a laptop, a tablet, or a phone. The latter two are often carried around by their owner and used anywhere and anytime. The use of smart phones and tablets for social interactions is very common amongst students. They will read books, have conversations, check email, and post to Facebook while having a cup of coffee or traveling on a train. The mobility and connectedness of these devices allows for use in a variety of places. Such pervasiveness cannot be ignored. Higher education faculty should not only be familiar with the sorts of activities that work well using mobile devices, but also aware of the strengths and weaknesses of mobile learning.

In 2010, the faculty at the University of Technology, Sydney received a grant to develop teacher expertise with emerging mobile technologies. We thought carefully about how we would involve the staff and get them enthusiastic about learning to teach in ways that exploited the use of mobile devices. The process of developing the staff subsequently became the topic of interest and we have since used this model of learning with teacher educators and school teachers.

\section{Developing a Learning Community}

When introducing new technologies into the classroom, it is important to provide support for educators. This can be successfully accomplished by creating a learning community. A professional learning community is a community of people who come together with a shared goal and a desire to grow and develop professionally. They develop a way of learning and also share what they learned with each other. 
In this project, we formed a professional learning community, which had a number of teacher educators and other members of the faculty from a variety of areas. Members had range of experience with mobile and other digital technologies, from being inexperienced to having extensive experience.

As part of the actions of the learning community, we used a process of action learning [1]. Fundamentally, action learning is learning by setting goals and acting to attain those goals. It works best with a community of people who may not have common goals but are able to discuss the goals they want to set; they then recount their experiences and any obstacles that may have occurred at their meetings in the community.

There were a number of important actions taken to progress learning in the community. These included the following:

1. Each member of the community set a personal goal concerning an area of mobile learning and teaching with which they might want to become familiar, and developed an action plan.

2. We met regularly to plan our actions and discuss our experiences of trialling pedagogical activities with mobile devices.

3. We held a number of workshops with external advisers who showed us the potential of the devices we were using.

4. We interviewed experts in the field of mobile learning and then discussed their views in our meetings.

5. We formed informal buddy support systems, where members of the community would get help from other members as needed.

\section{Setting Goals}

The community started with goals that were achievable and not too daunting. The idea was to gain confidence from the process. The following table shows examples of a few of the goals that were set and put into action [3].

\begin{tabular}{|l|l|}
\hline $\begin{array}{c}\text { Examples of pedagogical } \\
\text { trials with mobile devices }\end{array}$ & \multicolumn{1}{|c|}{ Details (from action plans) } \\
\hline $\begin{array}{l}\text { Evaluation and use of } \\
\text { smartphone applications } \\
\text { ('apps'). }\end{array}$ & $\begin{array}{l}\text { Investigation of usable apps by teacher educators and their } \\
\text { students. This subsequently expanded to creation of subject- } \\
\text { specific apps. }\end{array}$ \\
\hline $\begin{array}{l}\text { Sharing through micro- } \\
\text { blogging. }\end{array}$ & $\begin{array}{l}\text { Trial of micro-blogging to support student teachers in their } \\
\text { school-based practicum. }\end{array}$ \\
\hline $\begin{array}{l}\text { Information access via } \\
\text { podcasts and screencasts }\end{array}$ & $\begin{array}{l}\text { Three members of the community also experimented with } \\
\text { podcasts for use in mobile learning settings, such as the } \\
\text { Sydney Botanical Gardens. }\end{array}$ \\
\hline
\end{tabular}




\begin{tabular}{|l|l|}
\hline $\begin{array}{l}\text { Digital capture of events } \\
\text { and images. }\end{array}$ & $\begin{array}{l}\text { Students of one member video recorded and photographed } \\
\text { artifacts or activities and uploaded these to a shared website } \\
\text { for discussion in science classes. }\end{array}$ \\
\hline Class-based surveys. & $\begin{array}{l}\text { A number of members had their students vote or provide } \\
\text { feedback through text messages and "quick-response" voting } \\
\text { applications. }\end{array}$ \\
\hline
\end{tabular}

\section{What Did We Learn?}

It became very obvious that for the community to succeed, the members needed to have a common interest and have stakes in investigating mobile learning. It was tempting to focus only on the use of mobile devices, as this was an easy aspect to work on. However, there was a more difficult task that needed attention. Primarily, investigating how to develop effective learning environments, and how to ensure the learning outcomes were achieved as a result of mobile device usage.

We needed to shift from a technocentric view of the process to thinking about learning and teaching, and focusing on how we could achieve the desired learning outcomes. In fact, subsequent emphasis on the underpinning theory about teaching and learning has led to our development of a Mobile Pedagogical Framework, which considers the characteristics of learning with mobile technologies and how those can be used for effective teaching [2]. The framework identifies a set of central dimensions for mobile learning: authenticity, collaboration, and personalisation. Locating activities on these dimensions allows for focus on the learning and teaching that occurs, rather than on the technology itself.

The process of working in the community has also led to a set of suggestions that may be useful to others looking to develop their knowledge about emerging technologies. These include the following:

- Enthusing and motivating the community members by exposing them to a variety of innovative and authentic activities mediated by the technology.

- Putting the thinking about teaching and learning before the thinking about the use of the technology.

- Investigating how the technologies might address existing problems of teaching and learning.

- Providing a safe environment within the community for experimenting with learning.

- Creating sufficient time for the community members to work on their goals.

- Encouraging a buddy system for support.

\section{Conclusion}


Our first venture into learning with mobile technologies taught us much about learning in a community. We have now used this learning to support many other learning communities with their action learning in relation to mobile technologies. Working in a supportive community enhances the experience and the outcomes.

Full details of this project may be found in "Mobilising teacher education: A study of a professional learning community" [3]. The author acknowledges Matthew Kearney, Peter Aubusson and Kevin Burden as the co-leaders of the project.

\section{References}

[1] Aubusson, P.J., Ewing, R. and Hoban, G. Action learning in schools: Reframing teachers' professional learning and development. Routledge, London, 2009.

[2] Kearney, M., Schuck, S., Burden, K., and Aubusson, P. Viewing mobile learning from a pedagogical perspective. Research In Learning Technology 20 (2012). DOI:10.3402/rlt.v20i0.14406

[3] Schuck, S., Aubusson, P., Kearney, M., and Burden, K. (2013). Mobilising teacher education: A study of a professional learning community. Teacher Development, 17, 1 (2013), 1-18

\section{About the Author}

Sandy Schuck is a Professor of Education in the School of Education at the University of Technology, Sydney. She is the Director of Research Training in the Faculty of Arts and Social Sciences. Her research interests concern teacher professional learning, particularly in mathematics education and in integrating technologies into teaching. 